\title{
EFFECTIVENESS OF THE PEDESTRIAN DETECTION STRATEGIES AND PAVEMENT MARKINGS: A DRIVING SIMULATOR STUDY
}

\author{
Qinaat Hussain, Wael K. M. Alhajyaseen, Ali Pirdavani, Kris Brijs, Khaled Shaaban, Tom Brijs
}

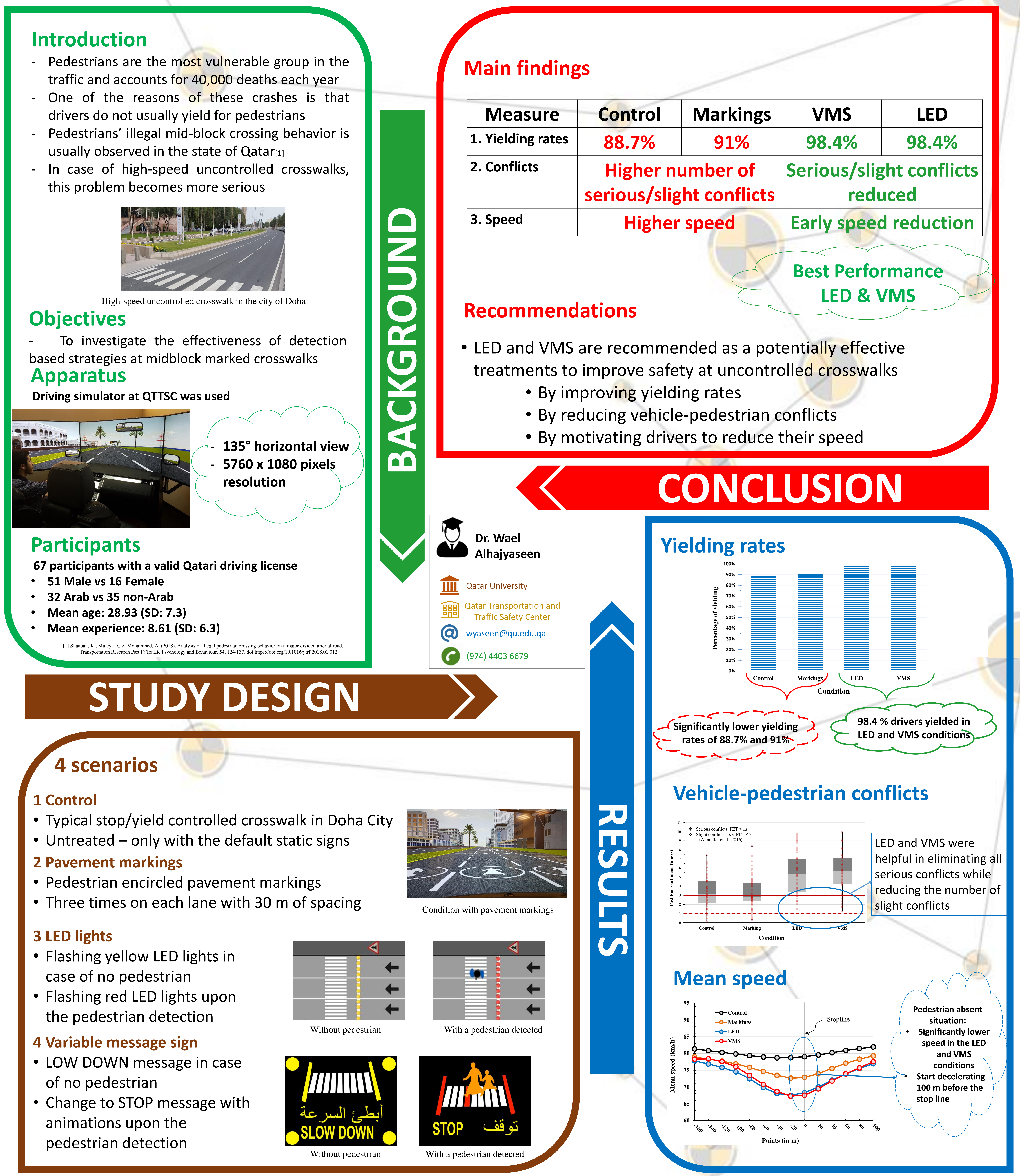

